\title{
On the Correlation between Iranian EFL Learners' Use of Metacognitive Listening Strategies and Their Emotional Intelligence
}

\author{
Parviz Alavinia $^{1} \&$ Hassan Mollahossein ${ }^{1}$ \\ ${ }^{1}$ Department of English Language and Literature, Faculty of Humanities and Letters, Urmia University, Urmia, \\ Iran
}

Correspondence: Parviz Alavinia, PhD, Assistant Professor, Faculty of Humanities and Letters, Urmia University, Valfajr 2 Blvd., Urmia, West Azerbaijan, Iran. E-mail: pevinia2006@yahoo.com

\author{
Received: August 11, 2012 Accepted: August 27, 2012 Online Published: October 12, 2012 \\ doi:10.5539/ies.v5n6p189 URL: http://dx.doi.org/10.5539/ies.v5n6p189
}

\begin{abstract}
The researchers in the current study were after gauging the would-be correlation between emotional intelligence (and its subcomponents), on the one hand and the use of listening metacognitive strategies by academic EFL learners on the other. The study at hand benefited from 72 female and 40 male university students from Urmia University, Urmia Azad University and Salams Azad University. The main instruments used in the study were Bar-On's emotional intelligence inventory and listening metacognitive strategies use questionnaire. Using Pearson correlation coefficient, the researchers came up with a significant amount of correlation between the use of listening metacognitive strategies and total emotional intelligence score as well as the learners' scores on the subscales of emotional intelligence (Intrapersonal, Interpersonal, adaptability, and general mood), with the mere exception of stress management. Moreover, the relationship between all the 5 subscales of emotional intelligence and the use of monitoring strategies, and the relationship between interpersonal skills and evaluating strategy were found to be significant.
\end{abstract}

Keywords: emotional intelligence, listening metacognitive strategies

\section{Introducation}

\subsection{Background}

Second language acquisition has been viewed as a complex cognitive process by cognitive psychologists as the learners implement some cognitive strategies during this process. As the studies show, not only do learners use cognitive strategies, but also they monitor and control their own mental processes (Pintrich, 1999), which are referred to as metacognitive strategies that are involved in learning and using language.

According to Oxford (1990), "metacognitive strategies help learners manage: (1) themselves as learners, (2) the general learning process, and (3) specific learning tasks" (cited in Carter \& Nunan, 2001, p.197). Simply put, "metacognition is thinking about thinking" (Flavell, 1979, p. 906). O'Malley and Chamot (1990), indicate that metacognitive strategies are "higher order executive skills that may entail planning for, monitoring or evaluating the success of a learning activity" (p.44).

Compared with other courses such as mathematics, learning English and generally learning language may be more pertinent to emotional intelligence. Yet, individual differences and personality traits like emotional intelligence are at times taken to play no role in teaching and learning system and are partially ignored. Despite the profusion of studies carried out regarding the role of IQ in academic achievement, very little seems to have been done concerning the relevance of EI to the use of strategies by learners.

As listening is an important medium of providing input for learners of English, finding optimum ways of teaching listening is a challenging task for EFL teachers and researchers. While research on strategies of second language learning has increased in recent years, studies on listening comprehension are so infrequent and the base for research in listening comprehension strategies is even so limited (Rubin, 1994). Recent studies carried out on the effective and less effective listeners, considering differences between their uses of strategies, indicate the important role of metacognitive strategies in success in listening (O'Malley \& Chamot, 1990; Vandergrift, 1997). Thus, finding methods of making learners aware of their use of metacognitive strategies and trying to improve the use of such strategies might help them enhance their general listening ability. 


\subsection{Significance of the Study}

Iranian students embark on learning English from the beginning of junior high-school; yet, English continues to be taught in higher levels of education, i.e. in high schools and universities. Although the most important skill they need to obtain in English is reading, as it is emphasized in educational system of Iran, it will be a forfeiture to put aside one of the important channels of obtaining information, i.e. the aural channel. Besides, the development of technology and computer offers us more and more access to information and aural channel becomes more important because multimedia is one of the greatest parts of modern technology. Thus, listening can be considered an important skill and it needs to receive more attention. In recent years, researches on language learning and teaching have confirmed the critical role of input in language learning (e.g. Dunkel, 1991; Feyten, 1991), emphasizing the role of listening in teaching methods. In the case of university EFL students (English literature, translation and teaching students), it becomes even more significant, because these students are more likely to become English teachers in the future and listening might feature as a challenging skill in their teaching practice. Thus, searching and finding better ways of teaching listening to these students is so important.

Using strategies of listening can help students better understand listening, and being aware of using these strategies can help them improve their strategies. By using metacognitive strategies, learners plan, monitor and evaluate their listening process. Teaching these strategies can accelerate their learning how to listen. Nowadays, psychologists and researchers in the field of education believe that a healthy school climate needs attention to affective and emotional learning as much as cognitive and academic learning. Since learners are different in emotional intelligence and other personality traits, they may choose different metacognitive strategies for listening. Thus, being aware of such learner differences and preferences might enable us to provide better ways of training our learners regarding the listening tasks, which can, in turn, bring about maximum absorption of aural input. Also, instructors might choose to classify students into different groups based on their emotional intelligence or other personality traits, and give them instructions to use metacognitive strategies in line with these traits. Though manifold studies, to date, have explored myriad facets of learners' emotional intelligence as well as their (metacognitive) learning strategies, the relationship between these two constructs and its salient role in the process of learning seems to have sunk into oblivion. Thus, the novelty and significance of the current investigation mainly lies in its attempt to deal with the less-attended issue of the relationship between learners' emotional intelligence, on the one hand, and their use of metacognitive strategies of listening, on the other.

\subsection{Research Questions}

Based on the research objectives, the following research questions were formulated in the current study:

Q1: Is there a significant relationship between Iranian university EFL learners' EQ and their use of listening metacognitive strategies?

Q2: Is there a significant relationship between Iranian university EFL learners' emotional intelligence scales and use of listening metacognitive strategies of 'planning', 'monitoring' and 'evaluation'?

Q2 : Is there any significant relationship between Iranian university EFL learners' EI scales and their use of metacognitive strategy of 'planning'?

Q2 $2_{\mathrm{b}}$ : Is there any significant relationship between Iranian university EFL learners' EI scales and their use of metacognitive strategy of 'monitoring'?

Q2 : Is there any significant relationship between Iranian university EFL learners' EI scales and their use of metacognitive strategy of 'evaluating'?

\section{Literature Review}

\subsection{A Brief History and Definition of EI}

Emotions are regarded as the common core for all human beings, yet what varies in individuals might be the ways in which they put emotions into use and handle them. The concept of emotional intelligence, which was introduced to the domain of psycholinguistics toward the end of the last millennium, comprises a set of abilities in individuals exerted for processing the emotional information. The early considerations of emotions and thought are related to philosophy and go back to early Greece. Aristotle argued that intellect was reliable, yet emotions were not deemed robust enough to constitute the foundation of rational thought (Bar-on, 2000).

Though the advent of the groundbreaking theory of Emotional Intelligence (EI) dates back to the end of twentieth century, its real origin is traced back to the concept of social intelligence which was given birth through attempts by Thorndike in 1920. He viewed social intelligence as the ability to empathize with others and act wisely in human relationships (cited in Goleman, 1998). The renewed interest in Thorndike's revolutionary 
thoughts in 1980s acted as the principal springboard for a reaapraisal of the interaction between emotion and reason. A key figure in the development and establishement of emotional intelligence, Gardner (1983) did a great deal in paving the way for the advent of this phenomenal concept, through his innovative look at the way intelligence was to be regarded, and by directing the attention of psychological community toward an array of intelligences rather than being confined to the static and conventional notion of unitary intelligence.

Later on, drawing on Gardner's line of argumentation, Salovey and Mayer (1990) broadened this dynamic conception of intelligence and put forth their new version of intelligence as "the ability to monitor one's own and others' feelings and emotions, to discriminate among them and to use this information to guide one's thinking and actions" (p. 189). It was at this point in the long-lasting history of intelligence that emotional intelligence got established as a self-contained discipline. First given momentum in 1980s, Salovey and Mayer's attempts were adopted and built upon by other renowned psychologists of the time, mainly by Goleman $(1995 \mathrm{a} / \mathrm{b})$ and Bar-On (1997). Goleman (1998), for instance, perceives emotional intelligence as "the capacity for recognizing our own feelings and those of others, for motivating ourselves, and for managing emotions well in ourselves and in our relationship" (p. 317). Bar-On (1997, p.14), on the other hand, delineates the term as "an array of noncognitive capabilities, competencies, and skills that influence one's ability to succeed in coping with environmental demands and pressures." Ever since its naissance, emotional intelligence has been approached from a variety of perspectives and given several conceptualizations. Yet, the fleeting glance at the evolutionary growth of EI provided here might suffice as an adequate ground for moving on to the next segment of the study which is after providing an account of the empirical research on emotional intelligence.

\subsection{Recent Empirical Research on Emotional Intelligence}

In a probe into the correlation between language institute teachers' emotional intelligence and their pedagogical success, Ghanizadeh and Moafian (2010) selected 89 EFL teachers from a number of English language institutes. The participants were then required to fill Bar-On's EQ-i. Moreover, to appraise the teachers' performance, another questionnaire entitled 'Characteristics of successful EFL teachers' was administered to the students taught by each teacher in their study. The analysis of the obtained data in this study "revealed that there is a significant relationship between teachers' success and EQ. Furthermore, significant correlations were found between teachers' EQ, their teaching experience, and their age" (p. 424).

In a later investigation, Labbaf, Ansari and Masoudi (2011) were after finding the potential effect of emotional intelligence on different dimensions of learning organization. To conduct the study, they randomly selected 86 respondents (education officials and Library assistants). Following the likert-type questionnaire analysis and resorting to the results of regression for the final analysis of data, they concluded that "EI had significant positive impact on dimensions of Learning Organization, clarity of mission and vision, effective transfer of knowledge and teamwork and group problem solving" (p. 536).

In their search for the possible effect of emotional intelligence and self-efficacy beliefs on high school students' achievement, Yazici, Seyis and Altun (2011) used a sample of 407 participants (236 female and 171 male high school learners). Successive to the analysis of data gained through emotional intelligence and self efficacy questionnaires, these researchers found that gender, age and self efficacy act as the major predictors of learners' academic achievement. Their study further came up with the existence of an interaction effect between academic achievement and the learners' socio-economic status. Moreover, females' academic achievement was reported to be significantly higher than that of male participants.

In their probe into the viable relationship between emotional intelligence and self-efficacy of Iranian EFL university professors, Alavinia and Kurosh (2012) faced a significant amount of correlation between the participants' scores on emotional intelligence and self-efficacy. The partakers of this study were some $50 \mathrm{EFL}$ university professors from whom the data were tapped through the use of Bar-On's EQ-i questionnaire and Tschannen-Moran and Woolfolk Hoy's self-efficacy scale. The final upshots of this study further revealed that the participants' ages and their years of teaching experience were of no interaction effect regarding the correlation between the subjects' emotional intelligence and their self-efficacy.

Finally, in an attempt to compe up with a lucid view as to the go-togetherness between EFL teachers' emotional intelligence and their burnout level, Alavinia and Ahmadzadeh (2012) used a sample of 75 high school EFL teachers who were then administered Bar-On's EQ-i and Maslach Burnout Inventory-Educators Survey. Subsequent to feeding the data into SPSS and running Pearson Product-Moment Correlations, regression analyses and independent-samples t-tests, these researchers found that a reverse correlation existed between the participants' EI and their burnout level, i.e. the more emotionally intelligent they were, the less they were found to suffer from burnout. Also, based on the findings of this study, "age and teaching experience were positively 
correlated with EI and reversely correlated with teacher burnout. Finally, significant differences among teachers' burnout (but not their EI) were found with respect to gender" (p. 37).

\subsection{Metacognitive Strategies of Listening}

It was Flavell (1979) who first coined the term 'metacognition', and defined 'metacognitive knowledge' as "consisting primarily of an understanding or perception of the ways in which different factors act and interact to affect the course and outcome of the cognitive enterprise" (Goh, 1997, p. 362). As he put it, "metacognition is thinking about thinking" (Flavell, 1979, p. 906). Wenden (1987) supposed that metacognition includes metacognitive knowledge and regulatory skills. Metacognitive knowledge involves knowledge about person (beliefs about attributes, learning styles, abilities, what learners know and do not know, and consciousness of one's progress), task (what learners know about demands and goals of the task, the ability to choose and assess the information) and strategy (knowing about what strategies should be used compatible to different types of tasks and a general knowledge about language learning). Regulatory skills are pre-planning (setting goals, selecting methods and materials, evaluating proficiency level and predicting the difficulty) and planning-in-action (monitoring, checking outcomes and improving plans). Oxford (1990) believes, "Metacognitive strategies help learners manage: (1) themselves as learners, (2) the general learning process, and (3) specific learning tasks" (cited in Carter \& Nunan, 2001, p. 197). In oxford's taxonomy metacognitive strategies include centering learning, arranging and planning learning, and evaluating learning (Oxford, 1990). In another categorization, O'Malley and Chamot (1990) divided learning metacognitive strategies into three groups of planning, monitoring, and evaluating.

According to Schraw and Dennison (1994), students who use metacognitive strategies more, seem to be superior to others in "planning, managing information, monitoring, debugging, and evaluating" (cited in Shia, Howard, \& McGee, 2005, p. 2). Santana (2003) found the important role of using metacognitive strategies among her students and claimed, "the single greatest predictor of language learning success among my students is the use of metacognitive strategies" (p. 3). In a study conducted by Ahmadizadeh (2001), a strong relationship was found between Iranian EFL learners' language proficiency level and their metacognitive strategy use. Many other research findings also show the great role of metacognition in predicting educational success and the ability of problem solving (e.g. Dunlosky \& Thiede, 1998; Thiede, Anderson, \& Therriault, 2003).

Metacognitive strategies do not only assist learners in learning in general but also have a lot to offer to listening skill specifically. Awareness of strategies in learning can have improving impacts on students' listening development (Victori \& Lockhart, 1995; Wilson, 2003). Yang (2009) indicates that one of the distinguishing factors that discriminates between successful and less successful listeners is learners' awareness of metacognitive strategies and he indicates that teaching metacognitive strategies helps listeners do the listening task more effectively. Likewise, Vandergrift (1997) indicates that metacognitive strategies contrast between a skilled and less skilled listener. Goh (2008) enumerates some positive effects of metacognitive strategy training on listening comprehension and states that it decreases learners' anxiety while listening and increases students' self-confidence. According to O'Malley and Chamot (1990) metacognitive strategies of listening include the attempt to plan, check, monitor, select, revise, and evaluate the listening process. Generally speaking, listening metacognitive strategies can be classified to pre-listening (planning), while-listening (monitoring), and post-listening (evaluation) strategies.

\subsection{Studies on Metacognitive Strategies of Listening}

Among the studies conducted on using and also training listening strategies, reference can be made to O'Malley Chamot, Stewner-Manzanares, Russo and Kupper's (1985) research, in which the effect of various amounts and types of strategy instruction on learning listening was explored. The results confirmed the fruitfulness of the instruction of listening strategies. In another study, Vandergrift (1999) demonstrated how teachers can foster the development of listening strategies and also how students can use the instructions to improve their learning. In still another investigation by Vandergrift (2003) on teen-age learners of French, it was indicated that skilled listeners used twice as many as metacognitive strategies compared with less skilled ones. Goh (2000), on the other hand, used a self-report questionnaire to elicit students' strategy use and strategy knowledge in listening comprehension task and she found that skilled listeners were more aware of their listening problems and strategies.

Some studies in this field have been done on the effect of teaching metacognitive strategies on listening comprehension performance. In a study by Thompson and Rubin (1996), for instance, the effect of teaching cognitive and metacognitive strategies of listening comprehension on American university students' language learning (Russian in the case of this study) was gauged. They found that in listening to video-recorded texts, 
learners who had received strategy instruction significantly surpassed those who had not received any instruction. Vandergrift and Tafaghodtari (2010) conducted a study on the instruction of listening comprehension metacognitive strategies in which strategies were taught sequentially. They intended to examine the effect of instruction on listeners' achievement and increase of their awareness of strategies. The results showed that their instruction was best fitted to less skilled listeners.

Nonetheless, there are some occasions of controversial allegations on the relationship between strategy use instruction and improving listening ability. For example, Field (1998) claimed that teaching listening strategies may promote the use of strategies but may not essentially result in listening ability improvement. Likewise, Cross (2009) conducted a study to investigate the effect of metacognitive strategy instruction on fifteen advanced-level Japanese students. The result did not show any significant difference between the control and experimental groups. These contradictory results show that the effect of metacognitive strategies instruction has to be investigated further.

\subsection{Studies on the Relationship between Emotional Intelligence and Use of Strategies}

As the concept of emotional intelligence is a partially novel and flourishing concept in relation to pedagogical attempts, studies dealing with the myriad implications of this construct for instructional arenas still appear to be infrequent. Among such educational issues which have received scant attention in the light of emotional intelligence lies the would-be relationship between learners' emotional intelligence and their use of metacognitive strategies. Among the very few studies in this regard, one can refer to Aghasafari's probe (2006) in which she found a significant correlation between overall emotional intelligence measure and language learning strategies.

In another study dealing with the interrelatedness of emotional intelligence and learning strategies, Hasanzadeh and Shahmohamadi (2011) launched a research project with 100 university learners majoring in different fields. Then, administering Bar-On's EQ-i and Learning and Study Strategies Inventory, they encountered a significant relationship between the learners' emotional intelligence and their learning strategies. Yet, in terms of the correlation between the learners' majors and their emotional intelligence and learning strategies no significant results were reported in this study.

\section{Method}

\subsection{Participants}

The current research was administered in three universities, i.e. Urmia University, Urmia Islamic Azad University and Salmas Azad University. The participants majored in English translation, TEFL and English literature for their bachelor's degree. Out of the entire sample (chosen through the administration of homogeneity test, i.e. TOFEL listening section), 72 were females and the remaining 40 were males. To provide more detailed information regarding the specifications of the participants, it must be said that the learners fell within the age range of 18 to 26. Further, sixty two of the participants were English literature students, 35 were English translation students, and 15 were TEFL students. Some of the students were native speakers of Persian and Kurdish but most of the participants' native language was Turkish. The summary of the participants' specifications is shown in tables 1 and 2 .

Table 1. Distribution of Subjects in Terms of Gender

\begin{tabular}{ccc}
\hline Gender & Frequency & Percent \\
\hline Female & 72 & 64.3 \\
Male & 40 & 35.7 \\
Total & 112 & 100.0 \\
\hline
\end{tabular}

Table 2. Distribution of Subjects in Terms of Majors

\begin{tabular}{lcc}
\hline Major & Frequency & Percent \\
\hline Literature & 62 & 55.35 \\
Translation & 35 & 31.25 \\
Teaching & 15 & 13.39 \\
Total & 112 & 100.0 \\
\hline
\end{tabular}




\subsection{Instrumentation}

The instruments used in this study comprised an emotional intelligence questionnaire, metacognitive strategies of listening questionnaire, and a test of listening comprehension. A detailed explanation of each instrument is provided below. Both questionnaires were in Persian. The reason behind using the Farsi version was that it was thought to take less time for learners to process questionnaire items, considering the fact that students were not native speakers of English language.

\subsubsection{Emotional Intelligence Questionnaire}

In order to measure the participants' emotional intelligence, Bar-On's EQ-i was administered. Bar-On's EI test is a self-report questionnaire which was designed by Bar-On in 1980s, to measure socially and emotionally intelligent behavior. The original version of the test included 133 questions, but through later attempts Bar-On reduced its size dramatically, so that the modified version comprised only 117 questions. Due to the fact that some questions were found irrelevant to Iranian context, Samouei (2003) developed a modified and translated version of the questionnaire which encompassed only 90 questions. With respect to its wide use in the Iranian context, this 90 -item version of the questionnaire was employed as the principal means of gathering data in the current study. It's worth noting that each of the items on the questionnaire is related to one of the 5 composite scales that comprise 15 subscale of emotional intelligence.

These scales and subscales are:

1) Intrapersonal skills (comprising subscales of Self-Regard, Emotional Self-Awareness, Assertiveness, Independence, and Self-Actualization)

2) Interpersonal skills (encompassing subscales of Empathy, Social Responsibility, andInterpersonal Relationship)

3) Stress Management (consisting of subscales of Stress Tolerance and Impulse Control)

4) Adaptability (including subscales of Reality-Testing, Flexibility, and Problem-Solving)

5) General Mood (being composed of subscales of Optimism and Happiness)

All the questions were scored on a five-point Likert-type scale ranging from 'strongly agree' to 'strongly disagree' following the questionnaire designer's lead. Samouei (2003, cited in Alavinia, 2011) found that this test did have sufficient reliability and validity indices in Iranian context. Based on her findings, the reported Cranach's alpha gained for the questionnaire was 0.93 , and the reliability index gained through odd-even, split-half method was 0.88. In another study, Dehshiri (2003, cited in Moafian \& Ghanizadeh, 2009) found the reliability index of 0.77 for the questionnaire.

\subsubsection{Listening Metacognitive Strategies Questionnaire}

Oxford's SILL is one of the most popular strategy inventories with good reliability (Khalil, 2005; Nyikos \& Oxford, 1993). It is a 50-item inventory designed for ESL and EFL learners, and extracts information about learner strategies for reading, writing, speaking, and listening. Ishler (2010) adopted and used it for extracting information about listening strategies used by Tunisian EFL learners. Since this study was concerned with metacognitive strategies of listening and was hence relevant to the focus of the current investigation, the questions related to metacognitive strategies adopted by Ishler were extracted and translated to Farsi. The new questionnaire contained 15 questions and each question was related to one of the metacognitive strategies of planning, monitoring and evaluation (each strategy was evaluated through 5 questions).

As the questions were translated to Farsi, the questionnaire was given to another translator to be rendered back to English to check any mismatch between the original English one and the translated version, and to correct any ambiguous parts in questions. In addition, to check the reliability of the new questionnaire, it was piloted with 25 students in Salmas Islamic Azad University and the reliability calculated through Cranach's alpha was 0.8. In spite of the fact that items of the questionnaire were adapted from Oxford's SILL, validity of the questionnaire was approved by one of the TESOL professors in Urmia University as well as two professors in Islamic Azad University of Urmia.

\subsubsection{Listening Comprehension Test}

Participants' listening comprehension ability was evaluated through the Listening comprehension part of a TOEFL test. The aim of evaluating the learners' listening skill at the outset of the study was to homogenize the participants in terms of their listening proficiency. The test comprised three parts and totally 50 questions. In part A, participants listened to short conversations between two people. After each conversation a question was asked 
and students had to answer them on their answer sheets. This part consisted of 30 conversations and consequently 30 questions. In Part B, there were two longer conversations between two people, with each conversation being followed by 4 questions. As a result, this part included 8 questions. Part $\mathrm{C}$ included three talks and each talk was followed by 4 questions (12 questions totally).

\subsection{Procedure}

The research was carried out in regular class time in three universities. The procedure of carrying out the research was more or less the same at three universities and different classes. At first, an explanation of the research was given to the participants including a brief explication regarding the concepts of emotional intelligence and metacognitive strategies. Then, the learners were made aware of what they were going to do. In order to increase their motivation to answer the listening test accurately and fill the questionnaires seriously, the researchers gave them a weblog address on which they promised to put the scores of the listening comprehension test and the results of the EQ questionnaire. The results and scores were put onto the weblog the day after the administration of each test.

Before starting each of the three parts of the listening test, a brief explanation was given to the participants about the types of questions they were going to encounter. This was done in order to give them an opportunity to make possible use of metacognitive strategy of planning. The whole listening comprehension test took 30 minutes. After listening comprehension test, the questionnaires of metacognitive strategies were given to the participants. It took nearly 10 minutes to fill them out. After collecting the questionnaires, a short break was given to the participants to rest. Then, EI questionnaire was distributed among the learners, which took about 15 minutes to be filled. The listening comprehension test and the questionnaires were scored and according to their listening scores, the participants were homogenized in data analysis procedure by omitting the outliers. Thus, later analysis of data was done with those falling one standard deviation above and below the mean.

\subsection{Data Analysis}

Finishing data collection, the researchers came up with three sets of data, i.e. listening comprehension scores, emotional intelligence (and its scales and subscales) scores, and listening metacognitive strategies and its components scores. It is worth mentioning that since the current research was concerned with emotional intelligence and its five scales, the scores of the subscales were not used. All the data were fed into computer. According to the research questions mentioned before, the following statistical analyses were run using SPSS 19:

1) Pearson Product Moment Correlation was used to find the potential relationship between total emotional intelligence scores and total scores of using listening metacognitive strategies.

2) Multiple Regressions analysis was used to find any probable relationship between 5 scales of EI and total scores of listening metacognitive strategies.

\section{Results and Discussion}

In this section, first the findings for each of the two research questions of the study will be presented and then a brief discussion of the gained upshots will follow.

\subsection{Findings Obtained for Research Question One}

Q1: Is there a significant relationship between Iranian university EFL learners' EQ and their use of listening metacognitive strategies?

A Pearson Correlation was computed to assess the relationship between participants' EQ and their use of metacognitive strategies in listening. Table 3 shows that there is a significant relationship between the two variables $(p<.05)$. This relationship is at the confidence level of .95. Thus, null hypothesis is rejected and the relationship between EQ scores and using metacognitive strategies is confirmed. The amount of the relationship is $\% 30$. 
Table 3. Test of Pearson Correlation between EQ and Metacognitive Strategies Scores

\begin{tabular}{llll}
\hline Correlations & EQ & Metacognitive Strategies use \\
\hline \multirow{4}{*}{ Motivation } & Pearson Correlation & 1 & $.30^{* *}$ \\
& Sig. (2-tailed) & .001 \\
N & 112 & 112 \\
\multirow{2}{***}{ Correlation is significant at the 0.05 level (2-tailed). } \\
\hline
\end{tabular}

\subsection{Findings Obtained for Research Question Two}

Q2: Is there a significant relationship between Iranian university EFL learners' emotional intelligence scales and use of each of the listening metacognitive strategies of 'planning', 'monitoring' and 'evaluation'?

Q2 2 : Is there any significant relationship between Iranian university EFL learners' EI scales and their use of metacognitive strategy of 'planning'?

Q2 : Is there any significant relationship between Iranian university EFL learners' EI scales and their use of metacognitive strategy of 'monitoring'?

Q2 : Is there any significant relationship between Iranian university EFL learners' EI scales and their use of metacognitive strategy of 'evaluating'?

Pearson Correlation and Multiple Regressions analyses were run to come up with satisfactory responses to the above research questions. The first step was to find the would-be correlations between EI scales and metacognitive strategies components (see Table 4).

Table 4. Correlation between Metacognitive Strategy of 'Planning' and EI Scales

\begin{tabular}{|c|c|c|c|c|c|c|c|}
\hline \multicolumn{8}{|c|}{ Correlations } \\
\hline & & 预 & 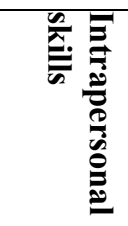 & 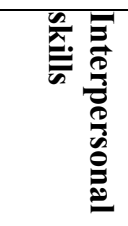 & 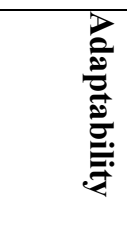 & 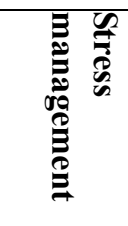 & $\begin{array}{l}0 \\
0 \\
0 \\
0 \\
0 \\
0 \\
0 \\
0 \\
0\end{array}$ \\
\hline \multirow{6}{*}{$\begin{array}{l}\text { Pearson } \\
\text { Correlation }\end{array}$} & Planning & 1.00 & & & & & \\
\hline & $\begin{array}{l}\text { Intrapersonal } \\
\text { skills }\end{array}$ & .12 & 1.00 & & & & \\
\hline & $\begin{array}{l}\text { Interpersonal } \\
\text { skills }\end{array}$ & $.25 * *$ & $.41 * *$ & 1.00 & & & \\
\hline & Adaptability & $.23 * *$ & $.70 * *$ & $.30 * *$ & 1.00 & & \\
\hline & $\begin{array}{l}\text { Stress } \\
\text { management }\end{array}$ & .110 & $.51 * *$ & $.18^{* *}$ & $.64 * *$ & 1.00 & \\
\hline & General mood & $.25 * *$ & $.69^{* *}$ & $.43^{* *}$ & $.56^{* *}$ & $.60 * *$ & 1.00 \\
\hline$* * p<.05$ & & & & & & & \\
\hline
\end{tabular}

Table 4 shows that the metacognitive strategy of 'planning' is correlated with 'Interpersonal skills', 'Adaptability', and 'General mood' $(p<.05)$. The correlation coefficients gained are as follow:

Interpersonal skills .25

General mood $\quad .25$

Adaptability $\quad .23$

Thus, the first null hypothesis is rejected and it is confirmed that there is a significant relationship between 
'planning' strategy and three scales of 'Interpersonal skills', 'General mood', and 'Adaptability'.

According to Table 5, \% 14 of the variance of the metacognitive strategy of 'planning' is determined by EI scales. Durbin-Watson test result (the value is 1.87 which is between 1.5 and 2.5) shows that the distribution of the errors is normal. Also, ANOVA shows the significance level of .00 $(p<.05)$. These two results show that regression of EI scales for predicting the use of metacognitive strategy of 'Planning' is appropriate.

Table 5. Durbin-Watson and ANOVA Analysis for 'Planning' Strategy

\begin{tabular}{cccccccc}
\hline & Model & $\mathrm{R}$ & $\mathrm{R}$ Square & $\begin{array}{c}\text { Std. Error of } \\
\text { the Estimate }\end{array}$ & Durbin-Watson & \multicolumn{2}{c}{ ANOVA } \\
\cline { 3 - 8 } 兽 & & & & & $\mathrm{F}$ & Sig. \\
\cline { 3 - 8 } & Enter & .37 & .14 & 84.70 & 1.87 & 3.43 & .00 \\
\hline
\end{tabular}

In order to determine the relative importance of each of the scales of EI vis-à-vis metacognitive strategy of 'planning', Standardized and non-standardized coefficients table has been drawn (Table 6). The absolute value of standard Beta shows the relative importance of each of the EI scales with regard to metacognitive strategy of 'planning':

$\begin{array}{ll}\text { Interpersonal skills } & \% 17 \\ \text { General mood } & \% 11 \\ \text { Adaptability } & \% 11\end{array}$

In line with the results, 'Interpersonal skills' has the greatest power and importance in using 'planning' strategy.

Table 6. Standardized and Non-Standardized Coefficients for 'Planning'

\begin{tabular}{|c|c|c|c|c|c|c|}
\hline \multicolumn{7}{|c|}{ Coefficients } \\
\hline \multirow[t]{2}{*}{ Model } & & \multicolumn{2}{|c|}{$\begin{array}{l}\text { Non-standardized } \\
\text { Coefficients }\end{array}$} & $\begin{array}{l}\text { Standardized } \\
\text { Coefficients }\end{array}$ & $\mathrm{t}$ & Sig. \\
\hline & & $\mathrm{B}$ & Std. Error & Beta & & \\
\hline \multirow[t]{4}{*}{1} & (Constant) & -18.57 & 91.32 & & -.20 & .83 \\
\hline & Interpersonal skills & 1.97 & 1.18 & .17 & 1.66 & .09 \\
\hline & Adaptability & 1.26 & 1.24 & .11 & 1.02 & .31 \\
\hline & General mood & 1.49 & 1.57 & .11 & .95 & .34 \\
\hline
\end{tabular}

Table 7 shows that there is a significant relationship between metacognitive strategy of 'Monitoring' and all the five scales of EI $(\mathrm{p}<0.05)$. Thus the second null hypothesis is rejected and it is confirmed that there is a significant relationship between 'Monitoring' strategy and five scales of EI. 
Table 7. Correlation between Metacognitive Strategy of 'Monitoring' and EI Scales

\begin{tabular}{|c|c|c|c|c|c|c|c|}
\hline \multicolumn{8}{|c|}{ Correlations } \\
\hline & & 㒸 & 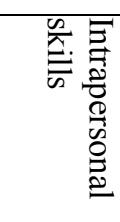 &  &  & 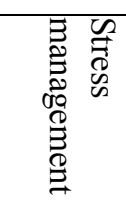 & $\begin{array}{l}0 \\
0 \\
0 \\
0 \\
0 \\
0 \\
0 \\
0 \\
0 \\
0\end{array}$ \\
\hline \multirow{6}{*}{$\begin{array}{l}\text { Pearson } \\
\text { Correlation }\end{array}$} & Monitoring & 1.00 & & & & & \\
\hline & $\begin{array}{l}\text { Intrapersonal } \\
\text { skills }\end{array}$ & $.36^{* *}$ & 1.00 & & & & \\
\hline & $\begin{array}{l}\text { Interpersonal } \\
\text { skills }\end{array}$ & $.32 * *$ & $.40 * *$ & 1.00 & & & \\
\hline & Adaptability & $.35 * *$ & $.70 * *$ & $.29 * *$ & 1.00 & & \\
\hline & $\begin{array}{l}\text { Stress } \\
\text { management }\end{array}$ & $.23 * *$ & $.52 * *$ & .19 & $.67 * *$ & 1.00 & \\
\hline & General mood & $.31 * *$ & $.69 * *$ & $.42 * *$ & $.56 * *$ & $.61 * *$ & 1.00 \\
\hline
\end{tabular}

The amount of each correlation is reiterated below:

Intrapersonal skills .36

Interpersonal skills .32

Adaptability $\quad .35$

Stress management .23

General mood $\quad .31$

Similar to 'Planning' strategy, Durbin-Watson and ANOVA results show that regression of EI scales for predicting the use of metacognitive strategy of 'Monitoring' is appropriate (Table 8). Also, it can be inferred that $\% 19$ of the variance of the metacognitive strategy of 'Monitoring' is determined by EI scales.

Table 8. Durbin-Watson and ANOVA Analysis for 'Monitoring' Strategy

\begin{tabular}{cccccccc}
\hline 章 & Model & $\mathrm{R}$ & $\begin{array}{c}\mathrm{R} \\
\text { Square }\end{array}$ & $\begin{array}{c}\text { Std. Error of } \\
\text { the Estimate }\end{array}$ & Durbin-Watson & \multicolumn{2}{c}{ ANOVA } \\
\cline { 3 - 8 } & & & & & $\mathrm{F}$ & Sig. \\
\cline { 3 - 8 } & Enter & .43 & .19 & 2.50 & 1.99 & 4.56 & .00 \\
\hline
\end{tabular}

In order to determine the relative importance of each of the scales of EI apropos metacognitive strategy of 'Monitoring', Standardized and Non-standardized coefficients table has been drawn (Table 9).

Table 9. Standardized and Non-Standardized Coefficients for 'Monitoring' Strategy

\begin{tabular}{|c|c|c|c|c|c|c|}
\hline \multicolumn{7}{|c|}{ Coefficients } \\
\hline \multirow{2}{*}{\multicolumn{2}{|c|}{ Model }} & \multicolumn{2}{|c|}{$\begin{array}{c}\text { Non-standardized } \\
\text { Coefficients }\end{array}$} & \multirow{2}{*}{$\begin{array}{l}\text { Standardized } \\
\text { Coefficients } \\
\text { Beta }\end{array}$} & \multirow[t]{2}{*}{$\mathrm{t}$} & \multirow[t]{2}{*}{ Sig. } \\
\hline & & B & $\begin{array}{l}\text { Std. } \\
\text { Error }\end{array}$ & & & \\
\hline \multirow[t]{6}{*}{1} & (Constant) & 7.22 & 2.62 & & 2.75 & .00 \\
\hline & Intrapersonal skills & .02 & .02 & .15 & 1.01 & .31 \\
\hline & Interpersonal skills & .06 & .03 & .19 & 1.92 & .05 \\
\hline & Adaptability & .06 & .04 & .19 & 1.36 & .17 \\
\hline & Stress management & -.01 & .03 & -.04 & -.32 & .74 \\
\hline & General mood & .01 & .05 & .04 & .30 & .76 \\
\hline
\end{tabular}


The absolute value of standard Beta shows the relative importance of each of the EI scales as to metacognitive strategy of 'Monitoring', the summary of which is briefed below:

$\begin{array}{ll}\text { Interpersonal skills } & \% 19 \\ \text { Adaptability } & \% 19 \\ \text { Intrapersonal skills } & \% 15 \\ \text { Stress management } & \% 4 \\ \text { General mood } & \% 4\end{array}$

The results show that the scales of 'Interpersonal skills' and 'Adaptability' have the greatest relative importance or power of predicting the use of metacognitive strategy of 'Monitoring'. In order to find the relationship between metacognitive strategy of 'Evaluating' and EI scales, Pearson Product Moment Correlation was run (Table 10).

Table 10. Correlation between Metacognitive Strategy of 'Evaluating' and EI Scales

\begin{tabular}{|c|c|c|c|c|c|c|c|}
\hline \multicolumn{8}{|c|}{ Correlations } \\
\hline & & 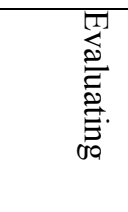 & 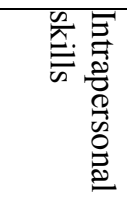 & 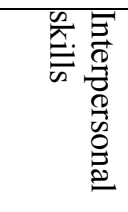 & 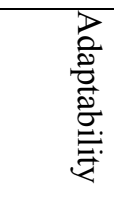 & 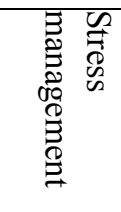 & 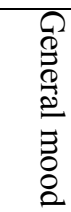 \\
\hline \multirow{6}{*}{$\begin{array}{l}\text { Pearson } \\
\text { Correlation }\end{array}$} & Evaluating & 1.00 & & & & & \\
\hline & Intrapersonal skills & .10 & 1.00 & & & & \\
\hline & Interpersonal skills & $.27 * *$ & $.41 * *$ & 1.00 & & & \\
\hline & Adaptability & .14 & $.71 * *$ & $.30 * *$ & 1.00 & & \\
\hline & Stress management & .04 & $.51 * *$ & $.18^{* *}$ & $.63^{* *}$ & 1.00 & \\
\hline & General mood & .09 & $.69 * *$ & $.43 * *$ & $.56^{* *}$ & $.60^{* *}$ & 1.00 \\
\hline
\end{tabular}

Table 10 shows that 'Interpersonal skills' has a significant correlation with metacognitive strategy of 'Evaluating' $(p<.05)$. Thus, the third null hypothesis is also rejected, and it is confirmed that there is a significant relationship between metacognitive strategy of 'Evaluating' and one of the scales of EI. Likewise 'Planning' and 'Monitoring' strategies, Durbin-Watson and ANOVA results show that regression of EI scales for predicting the use of metacognitive strategy of 'Evaluating' is appropriate (Table 11). Furthermore, as Table 11 indicates, $\% 7$ of the variance of the metacognitive strategy of 'Planning' is determined by EI scales.

Table 11. Durbin-Watson and ANOVA Analysis for 'Evaluating' Strategy

\begin{tabular}{|c|c|c|c|c|c|c|c|}
\hline \multirow{3}{*}{ 先 } & \multirow[t]{2}{*}{ Model } & \multirow[t]{2}{*}{$\mathrm{R}$} & \multirow{2}{*}{$\begin{array}{c}\mathrm{R} \\
\text { Square }\end{array}$} & \multirow{2}{*}{$\begin{array}{l}\text { Std. Error of } \\
\text { the Estimate }\end{array}$} & \multirow[t]{2}{*}{ Durbin-Watson } & \multicolumn{2}{|c|}{ ANOVA } \\
\hline & & & & & & $\bar{F}$ & Sig. \\
\hline & Enter & .27 & .07 & 3.03 & 1.97 & 8.96 & .00 \\
\hline
\end{tabular}

In order to determine the relative importance of 'Interpersonal skills' vis-à-vis metacognitive strategy of 'Evaluating', Standardized and non-standardized coefficients table has been drawn (Table 12). The absolute value of standard Beta shows that the relative importance of 'Interpersonal skills' for predicting the use of metacognitive strategy of 'Evaluating' is $\% 27$. 
Table 12. Standardized and Non-Standardized Coefficients for 'Evaluating' Strategy

\begin{tabular}{lllllll}
\hline \multicolumn{7}{c}{ Coefficients } \\
\hline Model & & \multicolumn{2}{l}{$\begin{array}{l}\text { Non-standardized } \\
\text { Coefficients }\end{array}$} & $\begin{array}{l}\text { Standardized } \\
\text { Coefficients }\end{array}$ & t & Sig. \\
\cline { 3 - 6 } & & B & $\begin{array}{l}\text { Std. } \\
\text { Error }\end{array}$ & Beta & \\
\hline 1 & & & & & \\
\hline & & 9.667 & 2.851 & & 3.391 & .001 \\
\cline { 2 - 6 } & Interpersonal skills & .113 & .038 & .275 & 2.994 & .003 \\
\hline
\end{tabular}

It is clear from the results that 'Interpersonal skills' is the only factor among five scales of EI that has the relative importance and predictive power (\%27.5) in using 'Evaluating' strategy.

\subsection{Discussion}

The results of the study indicated a positive relationship between learners' emotional intelligence and their use of metacognitive strategies. The survey of the relationship between EI scales and metacognitive strategies components showed correlation between 'Intrapersonal skills' and 'Monitoring', between 'Interpersonal skills' and three components of metacognitive strategies (Planning, Monitoring, Evaluating), between 'Adaptability' and 'Planning' as well as 'Monitoring'. The 'Stress management' scale had correlation only with 'Monitoring' strategy. Moreover, 'General mood' had correlations with 'Planning' and 'Monitoring'. The only metacognitive strategy of listening with which all EI scales correlated was 'Monitoring' strategy.

The studies related to the relationship between EI and strategies are so scant. However, the findings of the study regarding the relationship between EQ and using metacognitive strategies are in line with the study of Aghasafari (2006) who found a positive relationship between overall EQ and language learning strategies. The findings of the study are also in line with Hasanzadeh and Shahmohamadi's (2011) study, where they found a positive relationship between Iranian learners' EQ and use of learning strategies. Nonetheless, it's worth noting that their study included all the learning strategies of four skills, whereas the present study investigated the effect of EI just on metacognitive strategies of listening. All in all, the results of the present study correspond with studies carried out concerning the relationship between EI and learning strategies. Yet, considering EI scales, they have some common and in some cases different results. This shows that there is a need for further studies concerning the relationship between the EI scales and strategies.

\section{Conclusion and Implications}

The results of the present study may have some implications for EFL teachers, learners and teacher trainers. The goal of educational system is to prepare learners for life, for coping with stressful and challenging situations. Emotionally intelligent people deal more effectively in these situations. This capability in handling stressful situations can be applied to listening tasks, as well. The more emotionally intelligent the learners are, the better and more strategies they are liable to use before, during and after the task. The results of this study confirmed this idea.

The findings of the current study also revealed a significant relationship between emotional intelligence and listening metacognitive strategies. Considering that EI is developmental (Davies, Stankov \& Roberts, 1998; Mayer, Salovey \& Caruso, 2000), language learners can be trained emotionally. Since emotions can be regarded as the mediators between sensory input and thinking, having a high emotional quotient may help learners be better receivers of input and they may consequently choose appropriate metacognitive strategies in listening tasks. Teachers can teach students to handle the listening task by using appropriate metacognitive strategies when they are in a stressful situation and this is a dimension of training emotional intelligence in learners. Instructors can further lead learners to know more about their feelings and emotions and reinforce their positive emotions. In addition, knowing about their own emotions can help them in developing goals, monitoring their success in doing tasks and evaluating what they have done. These are metacognitive strategies that learners can use considering their emotional intelligence.

Language teachers can classify students into separate groups regarding emotional quotient, and consider that students with lower EQ are probably less successful users of metacognitive strategies and teach them metacognitive strategies according to their EQ. Since the results of this study revealed that compared to other scales of EI, 'Interpersonal skills' and 'Adaptability' are more powerful predictors of metacognitive strategy use 
in listening tasks, teachers can train learners to be more social in classroom and adaptable to new listening tasks. This may help them use more appropriate metacognitive strategies in listening, which, in turn, might result in having a more productive and supportive learning environment. Finally, language teacher trainers can instruct language teachers to consider their learners' emotional intelligence as one of the dimensions of individual differences and help them take appropriate steps in teaching metacognitive strategies to learners.

\section{References}

Aghasafari, M. (2006). On the relationship between emotional intelligence and language learning strategies. Unpublished master's thesis, Allameh Tabataba'i University, Iran.

Ahmadizadeh, Z. (2001). On the use of metacognitive strategies by Iranian EFL learners in conventional and distance learning systems. Unpublished masters' thesis, University of Tehran.

Alavinia, P. (2011). Emotional Engineering through the Application of Fuzzy Logic: Enhancing Emotional Intelligence by Raising Awareness of Emotions. Germany: VDM Verlag.

Alavinia, P., \& Ahmadzadeh, T. (2012). Toward a Reappraisal of the Bonds between Emotional Intelligence and Burnout. English Language Teaching, 5(4), 37-50. http://dx.doi.org/10.5539/elt.v5n4p37

Alavinia, P., \& Kurosh, S. (2012). On the Would-be Bonds between Emotional Intelligence and Self-efficacy: The Case of Iranian EFL University Professors. Theory and Practice in Language Studies, 2(5), 956-964. http://dx.doi.org/10.4304/tpls.2.5.956-964

Bar-On, R. (1997). Emotional Quotient Inventory: Technical Manual. Toronto: Multi Health Systems.

Bar-On, R. (2000). Emotional and social intelligence.Insights from the emotional quotient inventory (EQ-i). In Bar-On, R. \& Parker, J. D. (Eds.), The Handbook of Emotional Intelligence (pp. 363-388). San Francisco: Jossey-Bass

Carter, R., \& Nunan, D. (Eds.). (2001). The Cambridge Guide to Teaching English to Speakers of Other languages. Cambridge: Cambridge University Press

Cross, J. (2009). Effects of listening strategy instruction on news videotext comprehension. Language Teaching Research, 13, 151-176. http://dx.doi.org/10.1177/1362168809103446

Davies, M., Stankov, L., \& Roberts, R. D. (1998). Emotional Intelligence: In search of an elusive construct, Journal of Personality and Social Psychology, 75(4), 989-1015. http://dx.doi.org/10.1037/0022-3514.75.4.989

Dehshiri, R. (2003). The Reliability and Validity of EQ-i in Iran's Context, Unpublished Master's Thesis. Allame Tabataba'i University, Tehran, Iran.

Dunkel, P. A. (1991). Listening in the native and second/foreign language: Toward an integration of research and practice. TESOL Quarterly, 25(3), 431-57. http://dx.doi.org/10.2307/3586979

Dunlosky J., \& Thiede, K. W. (1998). What makes people Experiment more? An evaluation of factors that affect self-paced Experiment. Acta Psycho logic, 98, 37-56.

Feyten, C. M. (1991). The power of listening ability: An overlooked dimension in language acquisition. Modern Language Journal, 75(2), 173-80. http://dx.doi.org/10.1111/j.1540-4781.1991.tb05348.x

Field, J. (1998). Skills and strategies: Towards a new methodology for listening. ELT Journal, 52, 477-493. http://dx.doi.org/10.1093/elt/52.2.110

Flavell, J. H. (1979). Metacognition and cognitive monitoring: A new era of cognitive development enquiry. American Psychologist, 34(10), 906-911. http://dx.doi.org/10.1037/0003-066X.34.10.906

Gardner, H. (1983). Frames of mind: The theory of multiple intelligences. New York: Basic Books.

Ghanizadeh, A., \& Moafian, F. (2010). The role of EFL teachers' emotional intelligence in their success. ELT Journal, 64(4), 424-435. http://dx.doi.org/10.1093/elt/ccp084

Goh, C. (1997). Metacognitive awareness and second language listeners. ELT Journal, 51(4), 361-369. http://dx.doi.org/10.1093/elt/51.4.361

Goh, C. (2000). A cognitive perspective on language learners' listening com-prehension problems. System, 28 , 55-75. http://dx.doi.org/10.1016/S0346-251X(99)00060-3

Goh, C. (2008). Metacognitive Instruction for Second Language Listening Development: Theory, Practice and Research Implications. Regional Language Centre Journal, 39(2), 188 -213. 
Goleman, D. (1995a). Emotional Intelligence. Bantman: New York.

Goleman, D. (1995b). Emotional intelligence: Why it can matter more than IQ. London: Bloombury.

Goleman, D. (1998). Working with Emotional Intelligence. Bantman: London: Bloomsbury.

Hasanzadeh, R., \& Shahmohamadi, F. (2011). Study of Emotional Intelligence and Learning Strategies. Procedia - Social and Behavioral Sciences, 29, 1824-1829

Ishler, J. M. (2010). The listening strategies of Tunisian university EFL learners: A strategy based approach to listening to oral English texts. Doctoral dissertation, Indiana University of Pennsylvania.

Khalil, A. (2005). Assessment of language learning strategies used by Palestinian EFL learners. Foreign Language Annals, 38(1), 108-117. http://dx.doi.org/10.1111/j.1944-9720.2005.tb02458.x

Labbaf, H., Ansari, M. E., \& Masoudi, M. (2011). The Impact of the Emotional Intelligence on Dimensions of Learning Organization: The Case of Isfahan University. Interdisciplinary Journal of Contemporary Research in Business, 3(5), 536-545.

Mayer, J. D., Salovey, P., \& Caruso, D. (2000). Models of Emotional Intelligence. In R. J. Sternberg (Ed.). Handbook of Human Intelligence, 2nd ed. (pp. 396-420). Cambridge, UK: CUP, 2000. http://dx.doi.org/10.1017/CBO9780511807947.019

Moafian, F., \& Ghanizadeh, A. (2009). The relationship between Iranian EFL teachers emotional intelligence and $\begin{array}{lllll}\text { their self-efficacy in Language Institutes. System, 37(4), } & \text { 708-718. }\end{array}$ http://dx.doi.org/10.1016/j.system.2009.09.014

Nyikos, M., \& Oxford, R. (1993). A factor analytic study of language learning strategy use: interpretations from information-processing theory and social psychology. The Modern Language Journal, 77(1), 11-22. http://dx.doi.org/10.1111/j.1540-4781.1993.tb01940.x

O’Malley, J. M., Chamot, A. U., Stewner-Manzanares, G., Russo, R., \& Kupper, L. (1985). Learning strategy applications with students of English as a second language. TESOL Quarterly, 19, 285-296.

O'Malley, J. M., \& Chamot, A. U. (1990). Learning Strategies in Second Language Acquisition. Cambridge: Cambridge University Press.

Oxford, R. L. (1990). Language learning strategies: What every teacher should know. NY: Harper \& Row /Newbury House. (now Boston: Heinle \& Heinle / Thomson International).

Pintrich, P. R. (1999). The role of motivation in promoting and sustaining self-regulated learning. International Journal of Educational Research, 31, 459-470. http://dx.doi.org/10.1016/S0883-0355(99)00015-4

Rubin, J. (1994). A review of second language listening comprehension research. Modern Language Journal, 8(2), 199-221. http://dx.doi.org/10.1111/j.1540-4781.1994.tb02034.x

Salovey, P., \& Mayer, J. (1990) Emotional Intelligence. Imagination, Cognition and Personality, 9(3), 185-211.

Samouei, R. (2003). Azmoune houshe hayajani (Bar-On's EQ-i). Tehran: Moasseseye Tahghighatie Olume Raftarie Sina.

Santana, J. C. (2003). Moving towards metacognition. Unpublished master's thesis, Universidad Panamericana, Guadalajara. Reprinted from http://www.readingmatrix.com/conference/pp/proceedings2005/santana.pdf

Schraw, G., \& Dennison, R. S. (1994). Assessing metacognitive awareness. Contemporary Educational Psychology, 19, 460-475. http://dx.doi.org/10.1006/ceps.1994.1033

Shia, R. M., Howard, B. C., \& McGee, S. (2005). Metacognition, Multiple Intelligence and Cooperative Learning. Psychology (On-line). Retrieved from http://www.cet.edu/research/pdf/intelligences.pdf

Thiede, K. W., Anderson, M. C. M., \& Therriault, D. (2003). Accuracy of metacognitive monitoring affects learning of texts. Journal of Educational Psychology, 95, 66-73. http://dx.doi.org/10.1037/0022-0663.95.1.66

Thompson, I, \& Rubin, J. (1996). Can strategy instruction improve listening comprehension? Foreign Language Annals, 29, 331-342. http://dx.doi.org/10.1111/j.1944-9720.1996.tb01246.x

Vandergrift, L. (1997). The strategies of second language (French) listeners: A descriptive study. Foreign Language Annals, 30, 387-409. http://dx.doi.org/10.1111/j.1944-9720.1997.tb02362.x

Vandergrift, L. (1999). Facilitating second language listening comprehension: acquiring successful strategies. ELT Journal, 53(3), 168-176. http://dx.doi.org/10.1093/elt/53.3.168 
Vandergrift, L. (2003). From prediction through reflection: Guiding students through the process of L2 listening. The Canadian Modern Language Review, 59(3), 425-440. http://dx.doi.org/10.3138/cmlr.59.3.425

Vandergrift, L., \& Tafaghodtari, H. M. (2010). Teaching L2 learners how to listen does make a difference: An empirical study. Language Learning, 60(2), 470-497. http://dx.doi.org/10.1111/j.1467-9922.2009.00559.x

Victori, M., \& Lockhart, W. (1995). Enhancing metacognition in self-directedlanguage learning. System, 23, 223-234. http://dx.doi.org/10.1016/0346-251X(95)00010-H

Wenden, A. (1987). Metacognition: an expanded view of the cognitiveabilities of L2 learners. Language Learning, 37(4), 573-597. http://dx.doi.org/10.1111/j.1467-1770.1987.tb00585.x

Wilson, M. (2003). Discovery listening: Improving perceptual processing. ELT Journal, 57, 335-343. http://dx.doi.org/10.1093/elt/57.4.335

Yang, C. (2009). A study of metacognitive strategies employed by English listeners. International Education Studies, 2(4), 134-139.

Yazici, H., Seyis S., \& Altun, F. (2011). Emotional intelligence and self-efficacy beliefs as predictors of academic achievement among high school students. Procedia Social and Behavioral Sciences, 15, 2319-2323. http://dx.doi.org/10.1016/j.sbspro.2011.04.100 